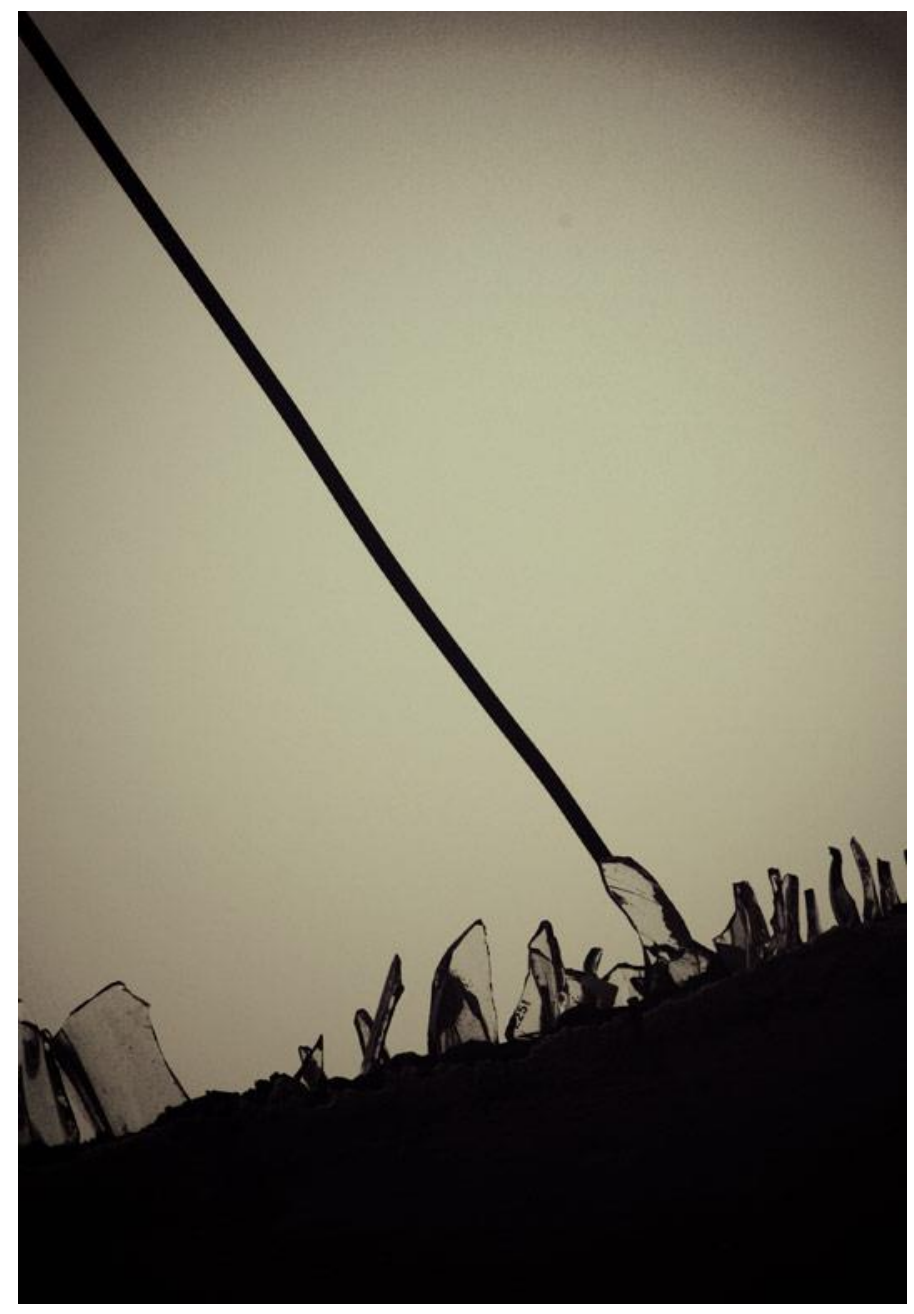

Adriano Facuri

\title{
rascunho [tardio] de um natal qualquer
}

\section{lenise regina}

Desconfia-se, desde que aprendeu a rabiscar círculos no papel, de que "Ienise" é um pseudônimo, e que "regina" é apenas um desejo antigo de nobreza. Está redatora publicitária até o próximo anúncio, quando então seu chefe descobrirá que "Lenise" é um pseudônimo e que "Regina" é apenas um desejo antigo de nobreza; sendo assim, ele não hesitará em lhe dar um pé na bunda e revelar-lhe-á que a monarquia no Brasil foi extinta desde 1889. Escreve para a Casa do Galo quinzenalmente às segundas-feiras, é revisora e redatora publicitária em BH.

Três crianças e bicicletas cor de rosa. Parelhas. Vestidos, também, cor de rosa. Laço de fita. Penso daqui, de onde vejo, que têm asas. Na garagem da casa barroca, um fusca de calotas 
brancas, espólio de um tempo de amor às pressas, amigos sumidos e necessidade constante de auto afirmação. A essas alturas, plug in baby já ia longe, indomável pelas frestas das portas e janelas, sorrio aliviado. Vivemos num outro século. Nenhum presente aberto ou mesmo frutas cristalizadas retiradas e ladeadas num prato de vidro, cascas das feridas arrancadas da pele do gordo panetone. A xícara vazia na mão e a sensação de algo que sempre falta. A tal casa, no meio da rua, divide o quarteirão em dois territórios com legislações bem distintas. Lá, os anjos voam e vez em quando, no fim da tarde, quando a noite vem, assim como uma nuvem leve, seu sopro pousa sobre as casas abafando o riso das crianças. Do outro lado, a mesma cor para as pedras, para os ratos, para as pessoas: cinza. Não há crianças e as máquinas mostram seus dentes, num gargalhar cíclico que ocupa toda a extensão do dia. Há miséria na falta e no excesso. Quando a bateria antiaérea soa e os olhos pipocam pelas frestas de cada janela; então podemos arriscar sem sombra de dúvida: um dos anjos cruzou a fronteira. 